DOI https://doi.org/10.30525/978-9934-26-173-2-51

\title{
FORMATION OF PROFESSIONAL CULTURE AS A PEDAGOGICAL PROBLEM DURING THE TRAINING OF FUTURE TEACHERS OF TECHNOLOGY IN HIGHER EDUCATION INSTITUTIONS
}

\author{
Shtainer T. V. \\ Lecturer of the department of technological and professional education \\ State Institution "South Ukrainian National Pedagogical University \\ named after K. D. Ushinsky" \\ Odessa, Ukraine
}

The current stage of development of the education system of Ukraine is characterized by its integration into the world educational space. This is accompanied by the creation of a new paradigm aimed at forming an educated, creative personality, providing conditions for the disclosure of abilities, use of experience, meeting the educational needs of the child. Understanding education as the acquisition by students of certain knowledge, skills and abilities and their preparation for life is rethought and replaced by looking at it as a sphere of human development, finding personal meaning in life.

Modern education requires the creation of innovative skills of professional development that will allow graduates of higher education institutions that are part of the world of production and management, to achieve high standards of professional culture. The presence of a document on professional, pedagogical higher education does not guarantee a teacher of technology to obtain a prestigious job in the specialty, so the training of a competitive specialist in a pedagogical institution of higher education is an important state problem. Solving the challenges facing the field of education, design, as well as "Technology" in Ukraine for its revival is impossible without the availability of highly qualified, competitive staff.

Considering the specifics of professional culture of future teachers of technology in higher education, we note that their training is consistent with global processes that have spread around the world, and affects the development of world culture in the professional activities of states and their society. As a result, the role of technology teachers in today's world is hard to overestimate. It connects between different types of technologies, such as information, innovation, design, projected etc. Accordingly, the future technology teacher must be a competent and professional cultural specialist.

Based on the above, we note that the component of professional culture is professional competence. 
First of all, it should be noted that in normative documents the concept of "Competence" is expressed as a dynamic combination of knowledge, skills and practical skills, thinking, professional, ideological and civic qualities, moral and ethical values that can successfully perform professional tasks and determine individual abilities and additional educational activities at a certain level of higher education [4].

Based on the interpretation of the concept of "Competence" we will analyze the scientific sources and reveal the concept of "Professional Competence".

Analyzing the scientific work of researchers L. Kutsak [3], O. Vitruk [6] and terminological dictionaries, we note the interpretation of professional competence as an integrated characteristic of personal qualities of a professional that reflects knowledge, skills, experience and moral status sufficient to achieve goals in a certain way professional activity [1], as well as the professional readiness and ability of the subject of labor to solve problems and perform their professional duties, which is the degree and the main criteria that determine the suitability of the subject for the position [5].

Due to the above, there is a growing need to train professional, competent and cultural future teachers in pedagogical institutions of higher education. The level of professionalism of teachers working in general secondary and vocational (vocational) education depends on the training of future professionals to study in higher education, which determines the training of specialists in various fields.

Investigating the phenomenon of "Professional competence of teachers", we agree with the researcher I. Gevko [2], who in his scientific work gives the concept such an integrated personal professional quality that allows modern teachers to perform official duties, professional tasks at a certain level and system education [2].

Based on the above, we turn to the phenomenon of "Professional competence of technology teachers", which is studied by many scientists.

Scientist L. Kutsak [3] in his article points out that the components of professional competence of technology teachers include: key competencies of technology teachers, which reflect the culture of teachers and are professional, social, motivated, informative, communicative, creative; special competencies of technology teachers who integrate knowledge on the subject of "technology" and are divided into: targeted, meaningful, project, reflective, monitoring [3].

The organization of the process of professional training of teachers of the technology of the future in higher education is a means of forming and developing professional competencies that ensure the formation of professional culture. 
In this regard, the concept of "professional training of future teachers of technology" is an integral part of higher education and its content includes training in a specialty that is part of the system of professional competence of future teachers of technology [7].

Analysis of research results, study of normative documents on training of applicants for pedagogical institutions of higher education, practical training, personal pedagogical experience and professional activity in higher education institutions, allowed to determine the structure of professional culture of future technology teachers.

It is established that the training of future teachers of technology in higher education is a purposeful, dynamic, organized educational process of development and accumulation by students of professional knowledge, skills, competencies developed necessary personal qualities, experience according to the qualifications of specialists specified areas and standards in the fields of education, technology.

\section{References:}

1. Guziy N. V. Terminological dictionary on the basics of training scientific and scientific-pedagogical staff of postgraduate pedagogical education. Kyiv : SHEI "University of Education Management", 2017. 230 p.

2. Hevko I. V. Formation of professional competence of the future teacher of technologies. Journal of education, health and sport. 2017.7 (7). P. 787-799. URL: https://doi.org/10.5281/zenodo.844085 (date of access: 12.11.2021).

3. Kutsak L. V. Peculiarities of formation of professional competence of future teachers of labor education in the conditions of professional training. Psychological and pedagogical aspects of formation of national elite (Problems and prospects of formation of national humanitarian and technical elite). 2010. P. 153-161.

4. On Higher Education : Law of Ukraine : as of January 1, 2019 / The Verkhovna Rada of Ukraine. Kyiv: Parlam. type, 2019. 119 p.

5. Short terminological dictionary. Donetsk. URL: http://dgma.donetsk.ua/ metod/ugo/pipvw/zo/kts.pdf (date of access: 15.09.2021).

6. Vitruk O. A. Formation of professional skills of the future teacher of technology in terms of training. Science and education. Odesa, 2014. Vol. 7. P. 40-47.

7. Zubyk L. V. Formation of professional competencies of future bachelors in information technology in the process of studying professional disciplines : dissertation ... of Candidate of Pedagogical Sciences : 13.00.04. Rivne, 2016. 342 p. URL: http://ep3.nuwm.edu.ua/4485/1/Дисертація Зубик\%20зах.pdf (date of access: 03.11.2021). 